\title{
CURRENT SITUATION OF MEAT-RELATED WASTE GENERATED BY FREE STATE ABATTOIRS, SOUTH AFRICA
}

\author{
Hester Roberts \\ Technikon Free State, School of Health Technology, South Africa
}

\begin{abstract}
Legislation exists which prescribes specific waste disposal methods, especially for condemned products, but financial constraints prohibits its implementation. Current legislation requires independent meat inspection but it is not yet applied at all abattoirs and will take a considerable period of time before it is in place. Meat inspection does not serve any purpose if condemned products returns to the food chain. Waste management practices at the different grades of abattoirs (Grades A to E) will be assessed and interviews with management will be used to predict the associated health risks to the community and the meat industry. Results obtained, will be used to construct a model to recommend the most suitable waste management system for each grade of abattoir in the Free State Province. This model would be appropriate for other provinces in South Africa.
\end{abstract}

Spoilage bacteria and pathogenic bacteria are found on the surfaces of meat products. Pathogenic bacteria can cause illness when these products are consumed (Aberle, et.al., 2001). Food borne illnesses are a world-wide phenomena that also play a role in South Africa. Duse (2002) quoted the Department of Health statistics indicating that in the period of January to June 1998 there were 110 cases of food poisoning and 3 deaths and in 1999127 cases reported and 0 deaths occurred. A large variety of bacterial genera have been recovered from red-meat, poultry and their products for example, Actinobacter, Aeromonas, Pseudomonas, Aalmonella, Zersinia, and Streptococcus.

An increase in amounts of waste are generated all over the world. Abattoirs are one of the industries that contribute to the problem of possible food-borne diseases and potential health hazards associated with food, especially meat (Bradshaw, et.al. 1992).

Waste generated by abattoirs include condemned organs and carcasses, blood, hides, paunch content and carcass trimmings. Condemned products and carcasses, unsuitable for human consumption, are eaten by „cavengers“ or persons living off refuse sites, and could cause a significant health problem which could lead to disease and death. 
KALMAR ECO-TECH'03

Bioremediation and Leachate Treatment

KALMAR, SWEDEN, November 25-27, 2003

Current economic conditions force under- privileged communities to seek any possible source of food and some of the sites frequented are landfill sites, dumping grounds and disposal sites used by abattoirs (Personal communication, Derbyshire, 2003).

\section{MEAT- AND WASTE-LEGISLATION}

South Africa does not have much legislation or Acts dealing with the disposal and handling of waste. South Africa is member state to the Basel Convention, but that deals more with the control of trans-boundary movement of hazardous waste, like for example waste from the chemical industry, and its disposal (Lombard, 2000).

In South Africa, the National Environmental Management Act 107 of 1998 (NEMA) was promulgated. Other legislation, for example the Constitution of the Republic of South Africa: Act 108 of 1996, the Bill of Rights as well as the Abattoir Hygiene Act, 1992 and the regulations framed thereunder and the Safety of Meat Act (Act 40 of 2000) all play an important role in food and waste management (Lombard, 2000).

With the promulgation of the Act on Abattoir Hygiene in 1992 (Act 121 of 1992) and the privatisation of meat inspections in 1993, a serious void was created with respect to the control of condemned products, as the act allowed that meat inspectors could be directly employed by the abattoir owners, which led to consequent intimidation as a result of the economic loss associated with condemnations.

Regulations framed under the Abattoir Hygiene Act, prescribes specific disposal methods, but financial constraints prohibit proper disposal as not all abattoirs possess incinerators, or else incorrect disposal methods are used. The Standing Regulations framed under the Abattoir Hygiene and Safety of Meat Act, form the basis for the handling and disposal of condemned products and came into effect in 1969.

One of the most important aspects of meat hygiene performed by abattoirs are primary meat inspections and control of condemned products. Meat inspections serve no purpose if the condemned products find their way back into the food chain (Personal communication, Derbyshire, 2003).

\section{CURRENT WASTE DISPOSAL METHODS}

Current waste disposal methods recommended for condemned products are:

- Incineration

- Denaturing

- Sterilisation in an approved sterilisation plant or 
- Any other method as approved by the Director: Veterinary Public Health.

Results analysed for 49 of the 95 red meat abattoirs in the Free State Province, South Africa indicated a specific trend. It is evident that the most common method used for disposal of condemned products was burying it (figure 1). Some vulture feeding also took place as well as condemned products being processed into by-products.

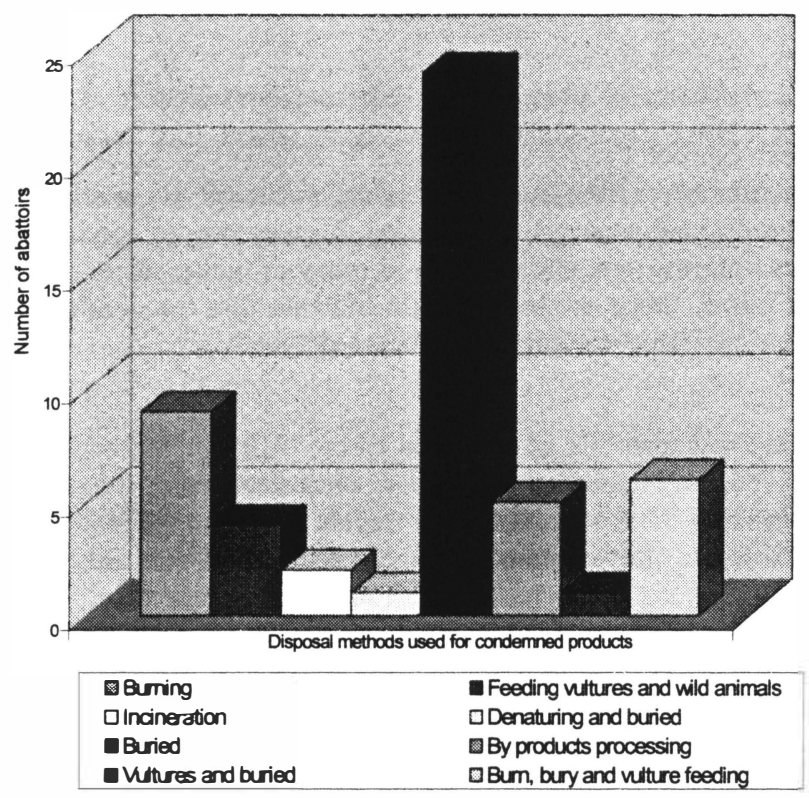

Figure 1: Disposal methods used for condemned products

Some abattoirs indicated that they bury the condemned products. The condemned products are placed into a trench or hole dug in the ground. There are no specific required depth, as long as unauthorised persons cannot access it. The trench or hole is then covered with soil. Open fire buming took place where condemned products were burned on open fires fuelled by using car tyres or diesel. Only a small amount of incineration took place and some of the respondents who indicated that they incinerated the condemned products could not supply any temperature which was reached in the incinerators. By product processing meant that the condemned products were processed into blood meal, carcass meal and bone meal which were respectively used for addition into pet food and fertilisers used for roses and flowers. Some respondents indicated that they burnt some condemned products, buried some other condemned products and some products were fed to vultures. 
KALMAR ECO-TECH'03

Bioremediation and Leachate Treatment

KALMAR, SWEDEN, November 25-27, 2003

As evident from figure 1 , the most common disposal method was burying. In Table 1, the areas where these condemned products were buried are discussed.

Table 1: Locations for burying condemned products

\begin{tabular}{|l|l|}
\hline Locations & Number of abattoirs \\
\hline Municipal landfill & 14 \\
\hline Private property/farms & 16 \\
\hline Abattoir premises & 7 \\
\hline Other premises & 1 \\
\hline
\end{tabular}

From table 1 it is can be seen that municipal landfill sites as well as private property or farms were most commonly used. The municipality would supply a site on municipal ground where the condemned products were buried. The burying of condemned products on private properties or farms took place widely as many of the abattoirs were situated on private property or farms. Other premises would indicate that the condemned products were transported from the place of slaughter and buried .

The disposal of blood was also one of the areas where different disposal methods were used (table 2). Here it can be seen that most blood were disposed of into municipal/local authority drainage systems. The second most common disposal method for blood were „run off into field“. Various other disposal methods are indicated in table 2.

Table 2: Methods of blood disposal

\begin{tabular}{|l|l|}
\hline Location & Number of abattoirs \\
\hline Municipal drainage & 20 \\
\hline Oxidation dams & 3 \\
\hline Buried & 6 \\
\hline Run-off into fields & 8 \\
\hline By products & 4 \\
\hline Reclaimed & 3 \\
\hline Farm & 2 \\
\hline Other methods & 2 \\
\hline
\end{tabular}

The blood which has to be disposed of, were mostly removed by municipal drainage systems for which abattoirs mostly had to pay a levy as they pose a strain on the drainage system. Some blood were buried. At eight abattoirs blood were allowed to run off into the fields (farm land). The blood disposed as by products were processed into blood meal, which was added as an ingredient into pet food and not used for human consumption at all. Three abattoirs indicated that they reclaimed the blood but did not supply any information regarding the use thereof. Two abattoirs indicated that it were disposed of on the farm and two abattoirs indicated that they applied another method of disposal. 


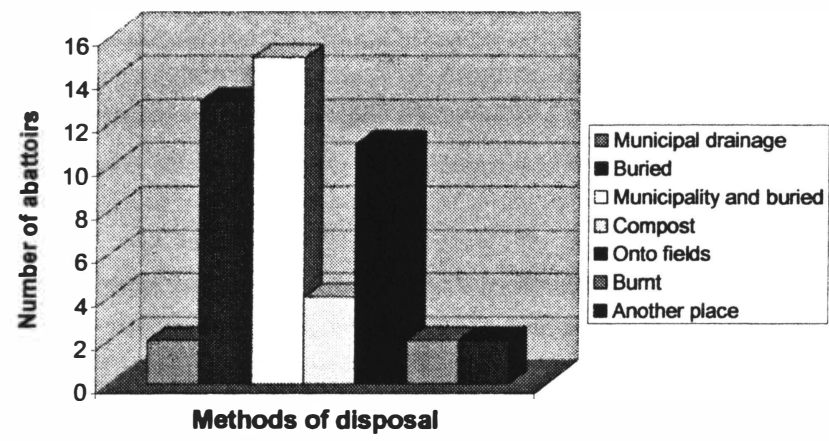

Figure 2: Disposal of stomach content

It is evident from the data depicted in figure 2 that most stomach contents are removed from abattoir premises by municipalities and buried $(n=15)$. Two abattoirs indicated that the stomach content enters the municipal drainage system. A large number of abattoirs (n $=13$ ) bury the stomach content. Composting is one of the disposal methods used for stomach contents $(n=4)$. A large component of the abattoirs $(n=11)$ indicated that the stomach contents are spread onto the fields. Only two abattoirs burnt the stomach contents and two abattoirs removed the stomach contents to other places.

The most common disposal method used for waste water was municipal drainage systems (table 3). Run-off into fields was seen as the second highest disposal method. Oxidation dams, French drains as well as tanks taken to municipalities or disposal of waste water into closed systems, before it is allowed to flow onto the fields, were used to a lesser extent.

Table 3: Waste water disposal methods

\begin{tabular}{|l|l|}
\hline Method of disposal & Number of abattoirs \\
\hline Municipal drainage & 26 \\
\hline French drains & 2 \\
\hline Closed systems into fields & 5 \\
\hline Run-off into fields/dams & 13 \\
\hline Oxidation dams & 2 \\
\hline $\begin{array}{l}\text { Into tank removed to } \\
\text { municipality }\end{array}$ & 1 \\
\hline
\end{tabular}


Two questions were asked to determine the perceptions of the abattoir owners and abattoir staff regarding the necessity of disposing of condemned products as well as to determine if they considered the consumption of condemned products by humans as safe. In only two cases, 2 abattoirs, indicated that they did not consider the disposal of condemned products necessary and the same respondents indicated that they considered it safe to supply these condemned products to humans for consumption. Table 4 indicates that the majority of the abattoirs considered disposal of condemned products necessary. Although a very high percentage

Table 4: Perceptions of importance of disposal and safety of condemned products

\begin{tabular}{|l|c|c|}
\hline & Yes & No \\
\hline Disposal of condemned products necessary & 46 & 2 \\
\hline Condemned products safe for human consumption & 2 & 46 \\
\hline
\end{tabular}

\section{CONCLUSION.}

Although this study is not yet completed, a definite trend is evident. Burying of condemned products was the most popular disposal method as expected. The disposal of waste water and stomach contents were mainly disposed into the municipal drainage system or removed by the municipality. This places strain on the disposal systems of municipalities/local authorities and in some cases the levy paid by abattoirs for the disposal of blood, stomach contents and waste water have a negative economic influence on the abattoirs. 